\title{
Seroprevalence of Pertussis in School-entry Age Children in Libya, A Cross-sectional Study*
}

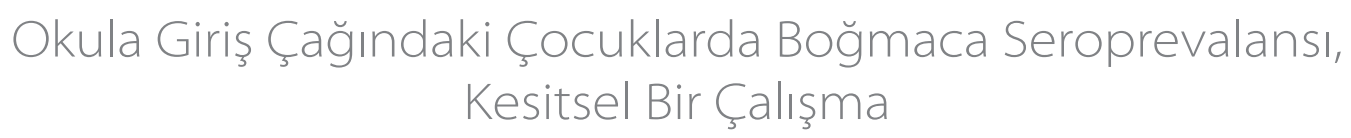

\author{
Suleiman Abusrewil', Mohamed Abugalia', Ali Ali' , Abdulla Abdulla', Ibtisam Hadid', Zakaria Alshanta' ${ }^{1}$, Hager Alkot ${ }^{1}$, \\ Othman Alshawsh', Mysone Abusrewil'
}

${ }^{1}$ Department of Pediatric Infectious Diseases, Libyan Scientific Society for Vaccination, Tripoli, Libya

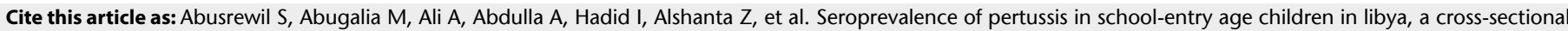
study. J Pediatr Inf 2018;12(3):e105-e109

* The $34^{\text {th }}$ Annual Meeting of the European Society for Paediatric Infectious Diseases, ESPID 2016 in Brighton, UK.

\section{Abstract}

Objective: In Libya, no pertussis booster doses are administered to children after 18 months of age. In light of evidence of waning of vaccineinduced immunity to pertussis, this study aimed to evaluate the waning of immunity in vaccinated school-entry age children, as measured by susceptibility to infection at population level. For this purpose, $\lg \mathrm{G}$ and IgA levels were measured as markers of recent (infection in the last 6 months) and non-recent infections (infection in the last 12 months).

Material and Methods: This was a cross sectional study undertaken in Tripoli, in February 2015. Children of school-entry age ( $>5$ to $\leq 7$ years) were recruited on convenience basis at vaccination centers. Sera were tested for antibodies to pertussis.

Results: Samples from 791 children (421 males and 370 females, mean age 6.50 were tested). All of the participants had received 4 doses of Whole cell pertussis containing vaccine in the first 2 years of life. The prevalence of recent and non-recent pertussis infection were $4.8 \%$ and $2.5 \%$, respectively. The proportion of children with undetectable level of $\lg G$ was 76.1.

Conclusion: The findings of this study showed significant circulation of Bordotella pertussis among vaccinated children by school-entry age. The circulation of $B$. pertussis in this population may be an indirect sign of waned immunity, which is simply corroborated by the absence of detectable antibodies in $76.1 \%$ of the children.

Keywords: Pertussis, Libya, child, school, Bordetella pertussis
Öz

Giriş: Libya'da 18. aydan sonra, herhangi bir boğmaca aşısı pekiştirme dozu uygulanmamaktadır. Aşı ile sağlanan boğmaca bağışıklığının azaldığını gösteren kanıtların ışığında, bu çalışma okula giriş çağındaki aşılanmış çocuklardaki bağışıklıktaki azalmayı, toplumsal seviyede enfeksiyona duyarlıı̆ı ölçerek değerlendirmeyi amaçlamaktadır. Bunun için IgG ve IgA seviyeleri yakın zamanda gerçekleşen (son 6 ayda) veya gerçekleşmeyen (son 12 ayda) enfeksiyon göstergeleri olarak ölçülmüştür.

Gereç ve Yöntemler: Bu çalışma Şubat 2015'te Trablus'ta gerçekleştirilen kesitsel bir çalışmadır. Okula giriş çağındaki çocuklar (> 5 ile $\leq 7$ yaş) aşı merkezlerinde uygunluk durumuna göre çalışmaya dahil edilmişlerdir. Alınan serumlarda boğmaca antikorları ölçülmüştür.

Bulgular: Çalışmada 791 çocuktan (421 erkek, 370 kız, ortalama yaş 6.5) alınan örnekler test edildi. Tüm çocuklar hayatlarının ilk iki yılında 4 doz tam hücreli boğmaca aşısı ile aşılanmıştı. Yakın zamanda gerçekleşen ve gerçekleşmeyen boğmaca enfeksiyonu sıklığı sırasıyla \%4.8 ve \% 2.5 idi. Çocukların \%76.1'i tespit edilemeyecek düzeyde IgG'ye sahipti.

Sonuç: Bu çalışma Bordetella pertussis dolaşımının okula giriş çağındaki aşılanmış çocuklardaki yüksek düzeyde olduğunu gösterdi. B. pertussis'in bu gruptaki dolaşımı, kendisini çocukların \%76.1'inde tespit edilebilecek miktarda antikor düzeyinin olmaması ile gösteren, azalan boğmaca bağışıklığının dolaylı bir göstergesi olabilir.

Anahtar Terimler: Boğmaca, Libya, çocuk, okul, Bordetella pertussis 


\section{Introduction}

Pertussis is a highly contagious and vaccine-preventable disease caused by the bacterium Bordotella pertussis (1). The illness is characterized by a prolonged, paroxysmal cough often accompanied by an inspiratory whoop (1). Disease presentation varies with age and history of previous exposure to the bacterium or vaccination (1). Before the availability of the vaccine in the 1940s more than 200.000 cases were reported annually, but that has decreased more than $80 \%$ in post-vaccination era in USA (1).

Despite high vaccination coverage, a resurgence of pertussis has been seen in certain countries (2). The absence of repeated boosting of the protective immunity either by immunization or exposure to infected persons (natural booster), resulting in waning over time of that protective immunity, was the main explanation for this reported reemergence (2). Hence, the waning of immunity after primary vaccination after a certain age is an issue.

Data from Sweden in a trial cohort showed that waning of immunity started at around school age, the first signs of waning immunity were observed at 6-7 years of age (3). A study from Turkey also reported low levels of protection in the 4-6 year age group where over half of this age group was negative for pertussis antibodies (4).

The immunization coverage for the third dose of diphtheria toxoid, tetanus toxoid and pertussis vaccine (DTP3) is high in Libya, maintained above $95 \%$ in the past 20 years (5). In 2013 Libya switched from whole cell to acellular pertussis vaccines and the current immunization schedule in Libya includes 3-dose acellular hexavalent pertussis vaccine (DTaPHB-IPV-Hib) given at 2, 4, and 6 months of age as primary immunization and then a booster dose at 18 months. Data from shows the number of reported cases of pertussis in 2012 as 197 (6). However, there is an overall lack of data related to laboratory confirmed cases of pertussis from Libya. The main reasons for this under reporting are lack of adequate diagnostic facilities, poor surveillance systems, and unawareness of physicians to the occurrence of these infections in adult population. In order to advocate for a booster at the school-age entry to address the issue of waning immunity, one would have to demonstrate a low level of immunity in-school age children, which is estimated at 6 years. Based on international evidence, the current pertussis vaccination schedule in Libya warrants investigation in the need for a booster at school-entry.

\section{Rationale}

Hence, the aim of conducting this study in Libya is to capture data on seroprevalence of antibodies to pertussis within this age group using serologic markers to provide evidence for this waning of immunity. Demonstration of a significant prevalence of recent infection by $B$. pertussis is indicative of broad circulation of the bacterium, which in turn, when measured at population level, suggests increased susceptibility in this population and thus waned protection. At present, no data is available in Libya on the duration of protection following the primary immunization series administered to infants in Libya. It is anticipated that the results of the study could be communicated to the National Immunization Technical Advisory Group (NITAG) in Libya in order to advocate and provide evidence for the rationale to introduce a booster dose of whooping cough vaccine in the schedule for school-age children.

\section{Study Objectives}

The overall aim of this study is to provide evidence of high proportions of children with recent infection indicating the waning of immunity in children at school entry in Libya in order to assess the need for booster vaccination for this age group after the primary series of pertussis immunization.

The primary objective is to measure the prevalence of antibodies to pertussis toxin (PT) (IgA and $\lg$ ) as markers of recent (infection in the last 6 months) and non-recent infections (infection in the last 12 months) in a sample of a selected population (greater than 5 years and $\leq 7$ years of age) in Libya. Secondary objectives are: to describe the distribution of this prevalence according to demographic and socioeconomic characteristics, such as household composition, in this sample of children of school entry age.

\section{Materials and Methods}

\section{Study Design}

This was a cross-sectional serological study conducted in the period between $1^{\text {st }}$ February and $31^{\text {st }}$ March, 2015. Children between ages of $5-\leq 7$ years residing in Tripoli, Libya were included in the study. Inclusion criteria were: children at school age ( 5 to $\leq 7$ years) with no pertussis vaccination in the last 12 months before participation in this study and not immuno-compromised children. The sampling were taken from at 12 immunization centers in different location in Tripoli when the children came in for immunization according to the regulations of school health department which require proof of immunization for school entrance as a compulsory condition for admission to first year primary school. A sampling frame developed based on geographical location and size of the catchment area of each health center and have been selected using probability proportional to size. Children from each health center were selected using systematic random sampling (i.e. every second child has attended the health facility for school vaccination program) until the required sample size was achieved. 
The sample size was calculated in order to reach a 0.05 precision on the $95 \%$ confidence interval of seroprevalence estimate, based on pertussis seroprevalence of studies in other countries in the Middle East and North Africa region, such as Turkey which found a 30\% seroprevalence in $<6$ years (7). Around 660 subjects with available data would be available. This number is taking into account the clustering by sampling within health centers. By anticipating $10 \%$ of subjects with no sampling results, 730 should be included in total in the study.

\section{Data and Sample Collection}

The questionnaire was filled by pediatrician. Sociodemographic information was obtained according to the study questionnaire from all guardian/parent of all study participants. The variables collected for each sample included: age, gender, place of residence, parental educational levels, and parents' occupation. Venous blood sample (3-5 mL) was extracted from each participant by well-trained pediatric nurses, stored in ice bag and transferred to the National Center for Disease Control (NCDC) laboratory on a daily basis.

\section{Laboratory Method}

Venous blood samples $(3 \mathrm{~mL})$ were taken and centrifuged at $3000 \mathrm{rpm}$ for $5 \mathrm{~min}$. Serum samples were stored at $-70^{\circ} \mathrm{C}$ and subsequently all samples were tested for the $\lg G$ and $\lg A$ antibodies levels specific to $B$. pertussis Toxin (PT) using the SeroPertussis $^{\mathrm{TM}}$ Toxin IgG and IgA kits according to the manufacturer's instructions. These kits are quantitative Enzyme Linked Immunosorbent assays (ELISA), in human serum or plasma (SavyonÒ Diagnostics Ltd, BMD, Marne-la-Vallée, France). The absorbance was measured with an ELISA reader (Biotek ELx800) with 450/620 $\mathrm{nm}$ filter. For test results calculation, we used the computerized method using MS-Excel ${ }^{\circledast}$ that is provided by the manufacturer.

In this study, an $\mathrm{lg} G$ concentration $\geq 40 \mathrm{IU} / \mathrm{mL}$ along with IgA concentration $<12 \mathrm{IU} / \mathrm{mL}$ was proposed for the categorization of recent infection during the last 12 months; an IgG concentration $\geq 100 \mathrm{IU} / \mathrm{mL}$ with any $\lg A$ concentration or an IgG concentration $\geq 40 \mathrm{IU} / \mathrm{mL}$ along with IgA concentration $\geq 12$ $\mathrm{IU} / \mathrm{mL}$ are proposed for the categorization of recent infection during the last 6 months. Cut-off values and interpretation of the results are shown in Table 1.

Table 1. Cut-off values for anti-PT antibodies and interpretation of the results

\begin{tabular}{|c|c|c|}
\hline Antibody & Value (IU/mL) & Interpretation \\
\hline $\begin{array}{l}\text { Anti-PT IgG } \\
\text { Anti-PT IgA }\end{array}$ & $\begin{array}{l}\geq 100 \\
\text { Any concentration }\end{array}$ & $\begin{array}{l}\text { Recent infection } \\
\text { (infection in last } 6 \text { months) }\end{array}$ \\
\hline $\begin{array}{l}\text { Anti-PT IgG } \\
\text { Anti-PT IgA }\end{array}$ & $\begin{array}{l}\geq 40 \\
\geq 12\end{array}$ & $\begin{array}{l}\text { Recent infection } \\
\text { (infection in last } 6 \text { months) }\end{array}$ \\
\hline $\begin{array}{l}\text { Anti-PT IgG } \\
\text { Anti-PT IgA }\end{array}$ & $\begin{array}{l}\geq 40 \text { and }<100 \\
<12\end{array}$ & $\begin{array}{l}\text { Non-recent infection } \\
\text { (infection in last } 12 \text { months) }\end{array}$ \\
\hline
\end{tabular}

\section{Data Analysis}

The primary outcome in this study was an estimate of the prevalence of recent infection as measured by quantitative evaluation of $\lg G$ and $\lg A$ antibodies to pertussis toxin according to defined thresholds. The data has been analyzed descriptively; Quantitative data has been reported using central tendency measurements (mean and median) and variability measurements (standard deviation and inter-quartile range). Categorical data has been described using proportions. The Chi-square test was used to assess the association between sociodemographic variables and the outcome (infection in the last 6 months/last 12 months). Multivariate logistic regression analyses adjusted for age, sex, occupation and educational level of parents and vaccination status was performed. Antibody level conforming to recent infection in the last 6 months was used as reference group. Data were analyzed using the Statistical Package for the Social Sciences (SPSS 20) program for statistical analysis (IBM, USA) and a $p$-value of $\leq 0.05$ was considered for statistical significance.

\section{Ethics Approval}

The study was approved by Libyan Ethical National Committee for Biological and Biomedical Science before commencement of study procedures. All participants provided written informed consent from one parent/guardian and before any blood samples were taken.

\section{Results}

A total of 791 children (421 males and 370 females) were tested. The mean of age was $6.5, S D \pm 0.29$. Table 2 demonstrates the demographic characteristics of the study population. All of the children included in the study were fully vaccinated according to the national immunization program.

Table 2. Demographic characteristics of the study population

\begin{tabular}{|l|c|c|}
\hline & No & Percentage \\
\hline Gender, males & 421 & 53.2 \\
\hline Occupation of parents & & \\
Father & 38 & $4.8 \%$ \\
$\quad$ Health professionals & 753 & $95.2 \%$ \\
$\quad$ Non- Health professionals & & \\
Mother & 28 & $3.5 \%$ \\
$\quad$ Health professionals & 763 & $96.5 \%$ \\
$\quad$ Non-Health professionals & & \\
\hline Educational level of parents & & \\
Father & 736 & $93.0 \%$ \\
$\quad$ University or above & 55 & $7.0 \%$ \\
$\quad$ High School & & \\
Mother & 282 & $35.7 \%$ \\
$\quad$ University or above & 504 & $36.7 \%$ \\
$\quad$ High School & 5 & $0.6 \%$ \\
\hline Primary & & \\
\hline
\end{tabular}


None of the study participants had an anti-PT IgG levels over $100 \mathrm{IU} / \mathrm{mL}$ and 163 (20.6\%) participants had IgG below level of quantification. Anti-PT IgG levels ranged from $0.5 \mathrm{IU} /$ $\mathrm{mL}$ to $70.5 \mathrm{IU} / \mathrm{mL}$ with a mean of $11.6 \mathrm{IU} / \mathrm{mL}$ (Standard deviation $=1.1$ ) while anti-PT IgA levels ranged from 0.4-35.7 IU/ $\mathrm{mL}$ with a mean of $5.4 \mathrm{IU} / \mathrm{mL}$ (Standard deviation=3.8). Thirty eight participants had anti-PT IgA levels $\geq 12 \mathrm{lU} / \mathrm{mL}$ indicating recent infection in last 6 months (Figure 1, Table 3).

There was no significant difference between the level of pertussis antibodies by sex among those studied $(p=0.55)$. Similarly, all other sociodemographic variables showed non statistically significant association with anti-PT antibodies level. Multivariate regression analysis between sociodemographic variables and anti-PT levels showed no significant relationship ( $p>0.05)$.

\section{Discussion}

The overall aim of our study is to provide data on the waning of immunity in children at school entry age in Libya in order to assess the need for booster vaccination for this age group.

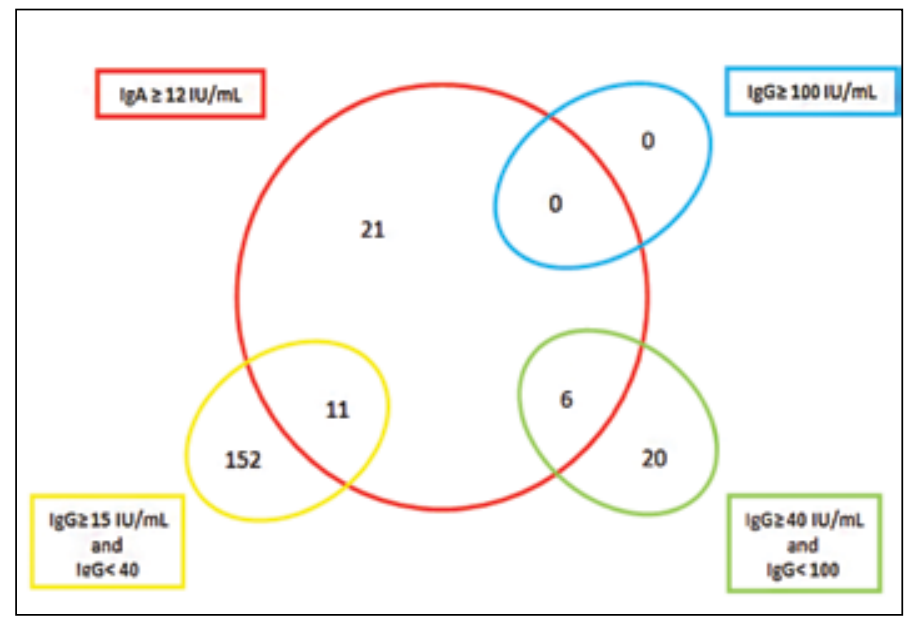

Figure 1. Number of children by their anti-PT IgG and IgA levels.

Table 3. Antibodies to pertussis toxin IgA and IgG

\begin{tabular}{|l|c|c|c|}
\hline Antibody & Value (IU/mL) & Interpretation & $\mathbf{n ~ ( \% )}$ \\
\hline Anti-PT IgG & $<15$ & Undetectable * & $581(73.4)$ \\
\hline Anti-PT IgG & $\geq 100$ & $\begin{array}{c}\text { Recent infection } \\
\text { (last 6 months) }\end{array}$ & 0 \\
\hline Anti-PT IgA & $\geq 12$ & $\begin{array}{c}\text { Recent infection } \\
\text { (last 6 month ) }\end{array}$ & $38(4.8)$ \\
\hline $\begin{array}{c}\text { Anti-PT IgG } \\
\text { Anti-PT IgA }\end{array}$ & $\begin{array}{c}\text { Non-recent } \\
\text { infection } \\
\text { (last 12 months) }\end{array}$ & $20(2.5)$ \\
\hline
\end{tabular}

* Below lower limit of quantification. The total will not add up to $100 \%$ as there are 11 children with anti-PT IgA of $\geq 12$ and anti-PT IgG between $\geq 40$ and $<100$.
The study results show that, after the primary series of pertussis immunization, the prevalence of recent infection in the last 6 months and the last 12 months among children aged 5-7 years was $4.8 \%$ and $2.5 \%$, respectively. The results had no association with sociodemographic characters of the study population.

Three quarter of studied children had low serum levels of $\operatorname{lgG}<15 \mathrm{IU} / \mathrm{mL}$, suggesting that a significant portion of the children are possibly at increased risk of disease. In addition, vaccine-induced immunity is thought to last 5-10 years and a waning of immunity makes school children in particular, as well as the older population, susceptible to the disease. Also, these children can be a main reservoir for disease in infants who have not completed their vaccination course, inadequately vaccinated children and for older susceptible population.

There are several studies that reported pertussis cases in school children, adolescents and adults, even in highly vaccinated areas (8-10). Although many studies have explained the seroprevalence of pertussis in industrialized countries, only few studies have reported its incidence in developing countries. This study showed that vaccine-induced immunity decreases by ages of 6-7 years, which was similar to the finding of several studies in the Middle East $(4,11,12)$.

In this study all participants have received the last dose of whole cell pertussis at the age of 18 month. In addition to waning immunity and adaptation of bacteria to the vaccine-induced immunity, the reappearance of pertussis might be explained by several factors such as demographic changes, changes in vaccine quality and changes in vaccine coverage (13).

A few limitations of the study should be acknowledged; the method of data collection may affect the representativeness of the study. However, the participants are randomly assigned, the studied children were not at different age groups (i.e. age bands prior to 6years and after 7 years for comparison). Another limitation is the use of anti-PT antibodies as markers of infection. Sero-epidemiological studies are documented as an important tool to assess the circulation of B. pertussis in societies and the evaluation of the immune status of populations (14). In addition, a high anti-PT titer has been proposed as an indicator of acute/recent infection $(14,15)$. Moreover, the recommended serological method for pertussis involves the measurement of IgG antibodies against pertussis toxin (IgG anti-PT). This is measured using the established cut-offs for definition of pertussis infection or protective immunity.

Various cut-offs have been used in the literature in studies on sero-prevalence and recommendations from the EU Pertstrain group (16). In addition, since pertussis vaccines induce high serum IgG levels that interfere with pertussis diagnostics, serum anti-PT IgA levels have provided an additional diagnostic role in our study (17). 


\section{Conclusion}

The findings of this study showed circulation of B. pertussis among vaccinated children by school-entry age. Previous research indicated that routine re-vaccination might be a logical approach to control a disease that does not confer permanent immunity (18). Since $76.1 \%$ of children in our study had undetectable levels of IgG, suggesting a possible increased risk of the disease, we recommend an additional booster dose of pertussis vaccines as a rational/possible strategy for disease prevention in the targeted age group and improved control of B. pertussis circulation in Libya.

\section{ACKNOWLEDGEMENT}

We sincerely acknowledged the cooperation of the children and their parents who participated in this project. We express our gratitude to the medical staff in department of pediatrics at Tripoli Medical Center for their great help in this project. Special thanks to Sanofi Pasteur for their scientific contribution in developing the methodology and design of the study, in reviewing and interpreting the results, and for providing the ELISA kits.

Ethics Committe Approval: The study was approved by Libyan Ethical National Committee for Biological and Biomedical Science before commencement of study procedures.

\section{References}

1. Centers for Disease Control and Prevention. Pertussis. In: Hamborsky $J$, Kroger A, Wolfe S (eds). Epidemiology and prevention of vaccinepreventable diseases. 13th ed. Washington DC: Public Health Foundation, 2015:261-78.

2. Ronn PF, Dalby T, Simonsen J, Jorgensen CS, Linneberg A, Krogfelt KA. Seroepidemiology of pertussis in a cross-sectional study of an adult general population in Denmark. Epidemiol Infect 2014;142:729-37.

3. Olin P, Gustafsson L, Barreto L, Hessel L, Mast TC, Rie AV, et al Declining pertussis incidence in Sweden following the introduction of acellular pertussis vaccine. Vaccine 2003;21:2015-21.

4. Cevik M, Beyazova U, Aral AL, Duyan Camurdan A, Ozkan S, Sahin F, et al. Seroprevalence of IgG antibodies against Bordetella pertussis in healthy individuals aged 4-24 years in Turkey. Clin Microbiol Infect 2008;14:388-90.

5. World Health Organization (WHO). Third dose of diphtheria toxoid, tetanus toxoid and pertussis vaccine. Reported estimates of DTP3 coverage. Available from: http://apps.who.int/immunization monitoring/globalsummary/timeseries/tscoveragedtp3.html Accessed on 13.12.2017.
6. World Health Organization (WHO). Pertussis reported cases Available from: http://apps.who.int/immunization_monitoring/ globalsummary/timeseries/tsincidencepertussis.html Accessed on 10.12.2017.

7. Inandi T, Guraksin A, Hacialioglu N. Seroprevalence of pertussis among children in Eastern Turkey. Public Health 2005;119:550-5.

8. Skowronski DM, De Serres G, MacDonald D, Wu W, Shaw C, Macnabb $J$, et al. The changing age and seasonal profile of pertussis in Canada. $J$ Infect Dis 2002; 185:1448-53.

9. Broder KR, Cortese $M M$, Iskander JK, Kretsinger K, Slade BA, Brown KH, et al. Preventing tetanus, diphtheria, and pertussis among adolescents: use of tetanus toxoid, reduced diphtheria toxoid and acellular pertussis vaccines recommendations of the Advisory Committee on Immunization Practices (ACIP). MMWR Recomm Rep 2006;55:1-34.

10. Celentano LP, Massari M, Paramatti D, Salmaso S, Tozzi AE; EUVACNET Group. Resurgence of pertussis in Europe. Pediatr Infect Dis $J$ 2005;24:761-5.

11. Duranoglu L, Sönmez C, Vurucu S, Kurtoglu D, Kesik V, Coplu N, et al. Evaluation of pertussis immunity status in schoolchildren immunized with whole-cell vaccine. Epidemiol Infect 2010;138:299-303.

12. Ozkan S, Aksakal FN, Tuzun H, Aycan S, Maral I, Cirak MY, et al. Bordetella pertussis seroprevalence among vaccinated school children in Ankara,Turkey. Infection 2007;35:387-9.

13. Mooi FR, van Loo IH, King AJ. Adaptation of Bordetella pertussis to vaccination: a cause for its reemergence? Emerg Infect Dis 2001;7(3 Suppl):526-8.

14. Giammanco A, Chiarini A, Maple PA, Andrews N, Pebody R, Gay N, et al. European Sero-Epidemiology Network: standardisation of the assay results for pertussis. Vaccine 2003;22:112-20.

15. de Melker HE, Versteegh FG, Conyn-Van Spaendonck MA, Elvers $L H$, Berbers $G A$, van Der Zee A, et al. Specificity and sensitivity of high levels of immunoglobulin $G$ antibodies against pertussis toxin in a single serum sample for diagnosis of infection with Bordetella pertussis. J Clin Microbiol 2000;38:800-6.

16. Guiso N, Berbers G, Fry NK, He Q, Riffelmann M, Wirsing von König CH;EU Pertstrain group. What to do and what not to do in serological diagnosis of pertussis: recommendations from EU reference laboratories. Eur J Clin Microbiol Infect Dis 2011;30:307-12.

17. Hendrikx LH, Öztürk $K$, de Rond LG, de Greeff SC, Sanders EA, Berbers $G A$, et al. Serum IgA responses against pertussis proteins in infected and Dutch WP or aP vaccinated children: an additional role in pertussis diagnostics. PLoS One 2011;6:e27681.

18. Orenstein WA. Pertussis in adults: epidemiology, signs, symptoms, and implications for vaccination. Clin Infect Dis 1999;28(Suppl 2):S147-50. 